\title{
People's knowledge and dependency on Rampur wetland of western Chitwan, Nepal
}

\author{
Rajesh Nepal ${ }^{1}$ and Dharma Raj Dangol $\bowtie^{2}$ \\ ${ }^{1}$ Institute of Agriculture and Animal Science, Tribhuvan University, Chitwan, Nepal \\ ${ }^{2}$ Natural History Museum, Tribhuvan University, Swayambhu, Kathmandu, Nepal \\ drdangol@gmail.com
}

\begin{abstract}
Understanding people's knowledge and their dependency on wetland forms the basis of conserving them. The paper assessed the status of wetlandin Rampur and local peoples' dependency on it, conducted in the year of 2013. Study revealed that majority of respondents noticed change in wetland in past years and in their priority, drying ranked first followed by decrease in acreage, and biodiversity loss. It was found that factors responsible for these changes were drought, encroachment, flooding, erosion and succession by invasive weed species. Study found that local peoples have several impacts on wetland which were conversion for agriculture, discharge of pollutants, overexploitation of aquatic resources, overgrazing, conversion for residential development, and conversion for aquaculture. However, Negative impacts of wetland were flooding, foul smell, incidence of insect pest/disease, coldness in winter, and bank cutting. It was found that people dependent on wetland for farming, fodder collection, fuel wood collection, medicinal plants, religious purpose, fishery, livestock grazing, wild edible plants, irrigation, commercial fishery and recreation. Study showed that local peoples have knowledge about several aspects of wetland and they are dependent for their livelihood. Therefore, in order to protect wetland from degradation, conservation and management activities need to be implemented properly with the involvement of local peoples.
\end{abstract}

Keywords: biodiversity, conservation, dependency, impacts,socioeconomic values

\section{INTRODUCTION}

Wetlands are among the most biologically productive ecosystems as they are rich in species diversity (Mwakaje,2009).Wetlands occupy approximately $5 \%$ of the total area of Nepal, ranging from high altitude glacial lakes to hot springs, ponds, ox-bow lakes to river flood plains, swamps to marshes (Adhikari et al., 2009).Wetlands have intrinsic values to communities living around them (Denny, 1995). Wetlands provide millions of people with materials, products and means of livelihood. Wetlands of Nepal have economic, ecological, aesthetic, socio-cultural and religious values. These ecosystems support a wide variety of plants and animals of economic value, and provide a wide range of goods and services as well as income-generating opportunities (MFSC, 2002). Apart from water security, wetlands contribute to local livelihoods, and especially for the poor in rural areas, who are most directly dependent on wetlands for their livelihoods (WI, 2006).

Despite the realization and wide documentation of their importance for biological, hydrological, economic and socio-ecological functions, they are some of the most threatened ecosystems 
in the world (Terer et al., 2004; MEA, 2005). Many parts of the world have experienced loss or degradation of wetlands on a huge scale because of agricultural use, urbanization, excessive exploitation by local populations, and ill planned developmental activities (Kabii, 1996). There are number of threats to wetlands in Nepal which are broadly categorized as habitat destruction and degradation, loss of ecosystem integrity, and depletion of species abundance and diversity (IUCN, 2004). Most of wetlands in country are facing problem of degradation due to conversion for other use and unsustainable use of resources. Nepal has shown its commitment to wetlands conservation, by signing the Ramsar Convention in 1987. Nepal has several legal and institutional arrangements relevant to wetland management. Several of them are related to overall biodiversity conservation and are thus also relevant to wetlands, whilst some are specific to wetland conservation. The Government of Nepal has endorsed National Wetland Policy in 2003 with the aim to conserve wetland biodiversity involving the local people in the management of Nepal's wetlands with the wise use of wetland resources (HMGN, 2003).

Wetland area in study site is a lowland freshwater marshy type of wetland located in Chitwan District, in the central inner terai of Nepal. The wetland has rich biodiversity and significant human use value. Dependency of local people on the wetland include agriculture, irrigation, fishing, medicinal and edible plants extraction, fuel wood and fodder extraction, picnic/recreation, religious and cultural importance. Major threats to wetland area are drying, conversion for other land uses, high wetland resource use, overgrazing by domestic livestock, loss of biodiversity, pollution and introduction/invasion of exotic plant species. Yet, till date there is no full documentation of wetland of Rampur. There were few research works carried out, mostly of them focused on biodiversity and physical aspects. So the study was conducted to find out peoples knowledge regarding wetland status and their dependency.

\section{MATERIALS AND METHODS}

\section{Study area}

The study site is located in the western part of Chitwan district in the central terai (fig. 1). It lies at a latitude of $27^{\circ} 38^{\prime \prime} 14.1^{\prime \prime} \mathrm{N}$ and longitude $84^{\circ} 21^{\prime} 25.2^{\prime \prime} \mathrm{E}$ and at an altitude of $257 \mathrm{~m}$. It is 9 $\mathrm{km}$ SW from the Narayangarh and the climate over there is tropical. Wetland is marshy and perennial in nature. Aquifers and springs are its sources of water. The wetland area covers an area of 15 ha and the climate is tropical. The major portion of study location is located in Shardanagar VDC while some part lies in Mangalpur VDC with eastern boundary as boundary of Institute of Agriculture and Animal Science (IAAS). The wetland area includes marshy land, grazing land, converted agricultural land and settlement area. 


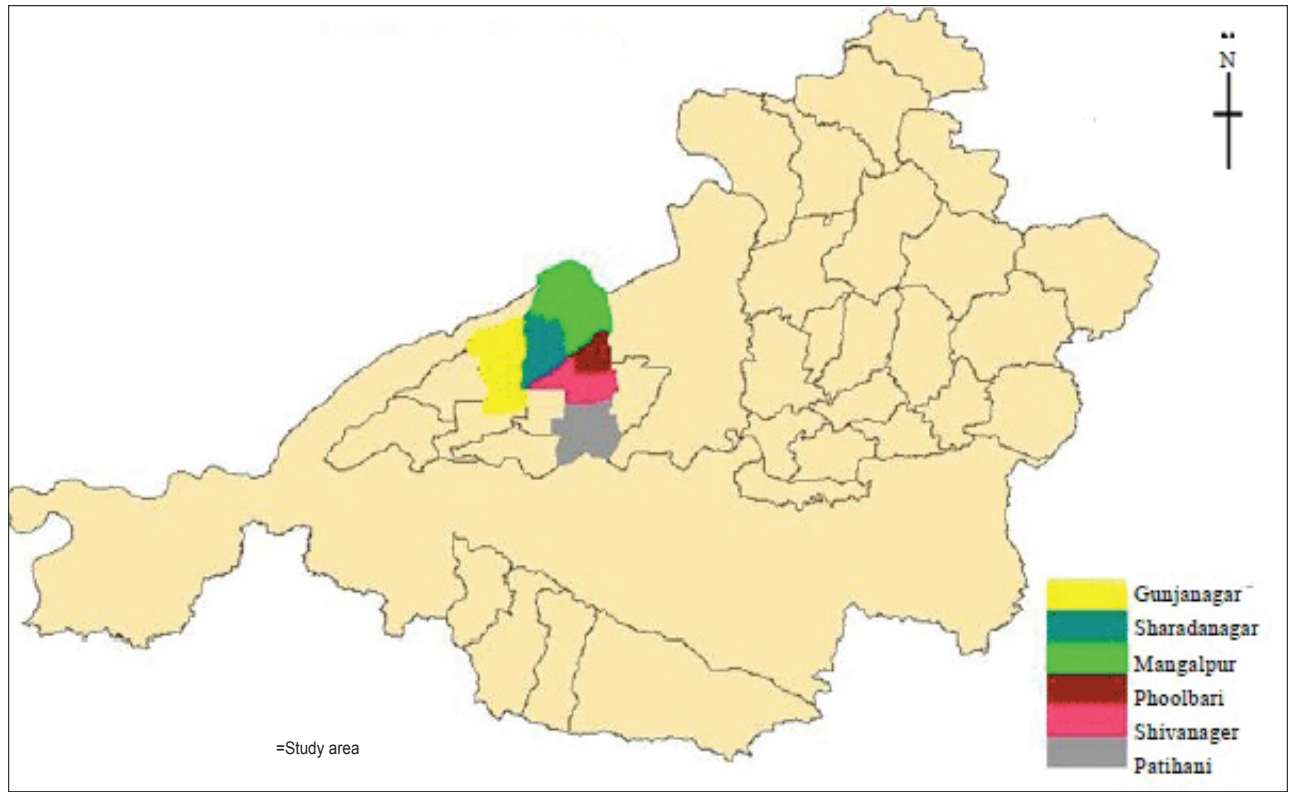

FIG. 1. Map of the Chitwan district showing surveyed VDCs.

\section{Data collection}

Participatory and exploratory research methods were used which included administration of questionnaires, key informant interviews, focus group discussion and field observations. Households were selected randomly by lottery from Mangalpur and Sharadanagar VDC such that $10 \%$ of households formed sample for interview. In total 120 households were selected through purposive random sampling consisting 83 households from Mangalpur and 37 households from Sharadanagar VDC. Then questionnaires were administered to 120 respondents, one from each selected households from both VDCs. Purposive sampling is a sampling technique in which researcher relies on his or her very specific need or purpose when choosing members of population to participate in the study. During the selection of the respondents, who are most dependent and visited wetland area frequently, were included in the sample, because they have knowledge about wetland regarding various aspects.

\section{Data analysis}

The information-coded data was statistically analyzed using SPSS version 16.0 software. Both descriptive and analytical methods were used to analyze the data.

\section{Indexing technique}

Scaling techniques provides the direction and extremity attitude of the respondent towards any proposition (Miah, 1993). Therefore, the scaling technique was used to construct index. The intensity of importance/reasons/problem faced by respondents was identified by using five point scaling technique using scores of $1.00,075,0.50,0.25$ and 0.00 . The formula given 
below was used to find the index for intensity of reasons/importance (Miah, 1993).

$$
\mathrm{I}_{\mathrm{imp}}=\Sigma\left(\mathrm{S}_{\mathrm{i}_{\mathrm{i}}} / \mathrm{N}\right)
$$

Where,

$$
\begin{aligned}
& \mathrm{I}_{\mathrm{imp}}=\text { Index value of importance } \\
& \Sigma=\text { Summation } \\
& \mathrm{S}_{\mathrm{i}}=\text { Scale value of } \mathrm{i}^{\text {th }} \text { importance } \\
& \mathrm{f}_{\mathrm{i}}=\text { Frequency of } \mathrm{i}^{\text {th }} \text { importance given by the respondents } \\
& \mathrm{N}=\text { Total number of respondents }
\end{aligned}
$$

\section{RESULTS AND DISCUSSION}

\section{General information of respondents}

The proportion of female respondents $(54.2 \%)$ was slightly higher than the male respondents $(45.8 \%)$. This is due to large number of males being outside their home for the purpose of employment. Hence, the sex ratio of the total respondents (male/female) was 0.85 . The sex ratio out of total population nationwide was 0.9 male/female (CIA, 2014). Sex ratio in Mangalpur and Sharadanagar VDC was 1 and 0.6 , respectively. This ratio was 0.9 in case of Mangalpur and 0.8 in case of Sharadanagar VDC (CBS, 2011). Majority $(46.7 \%)$ of respondents was indigenous followed by Brahmin (29.2\%), Occupational castes $(12.5 \%)$ and Kshetri $(17.7 \%)$. The literacy rate of the respondents was $83.3 \%$ in which larger proportion of female $(12.5 \%)$ were illiterate than male $(3.3 \%)$. The literacy rate of the study area $(83.3 \%)$ was well above the national average of $48.6 \%$ (CBS, 2011). This is consistent with the fact that wetland area is situated near from Bharatpur Municipality, so local peoples have easy access to educational institutions. Occupation of majority of respondents $(58.3 \%)$ was agriculture and others $(41.7 \%)$ were engaged in off farm activities. Paddy, maize and millet were major staple crops grown by farmers. Farmers were found adopting livestock production system with agriculture production where majority ( $84.2 \%)$ of them has one or more kind of livestock. The average monthly cash income of respondents was NRs. $16200 \pm 1274.56$ and ranged from NRs. 100000 per month to NRs. 1000 per month. Agriculture was primary source of income whiles others were fisheries, service, business, remittance and wage labour.

\section{Changes in wetland}

Perception of wetland change:The study showed that majority of respondents $(78.0 \%)$ felt change in wetland over long time (fig. 2). 


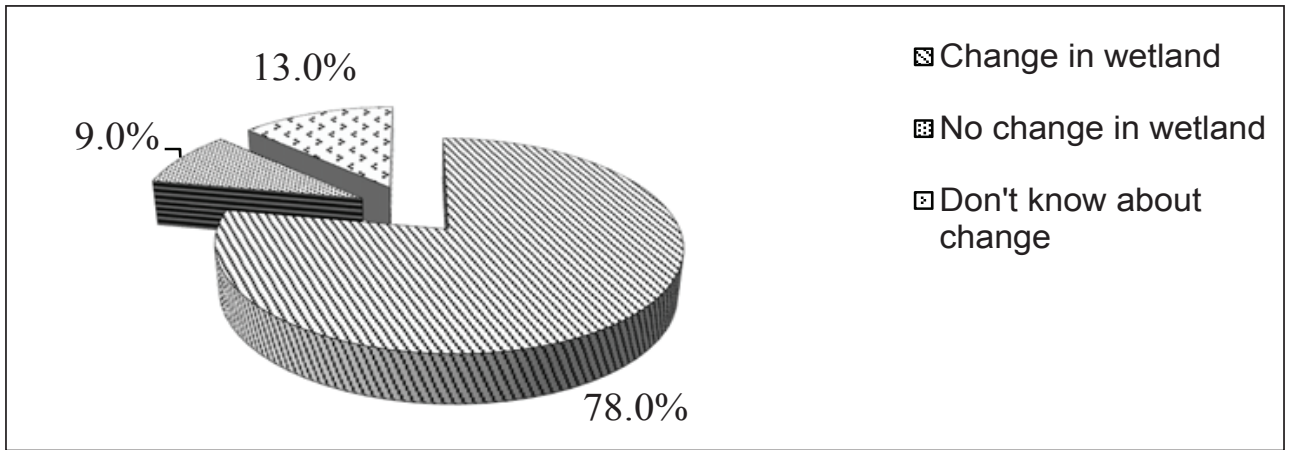

FIG. 2. Response to wetland area change by respondents.

Wetland changes and their ranking: The study showed that respondents from the Mangalpur and Sharadanagar VDC highlighted drying as the most important change in wetland with index value of 0.55 (table 1).

TABLE 1. Wetland changes and indexing on the basis of respondent's perception.

\begin{tabular}{|l|l|l|}
\hline Changes in wetland & Index value & Rank \\
\hline Drying & 0.55 & I \\
Decrease in acreage & 0.14 & II \\
Biodiversity loss & 0.13 & III \\
\hline
\end{tabular}

Note: Scale value ranges from 1 to 0 , where $1=$ most serious, $0.75=$ serious, $0.5=$ moderate, $0.25=$ a little bit and $0=$ no problem

Reasons behind change in wetland: It was found that major reason behind change in wetland was drought (fig. 3) as noticed by majority of respondents (35.1\%).

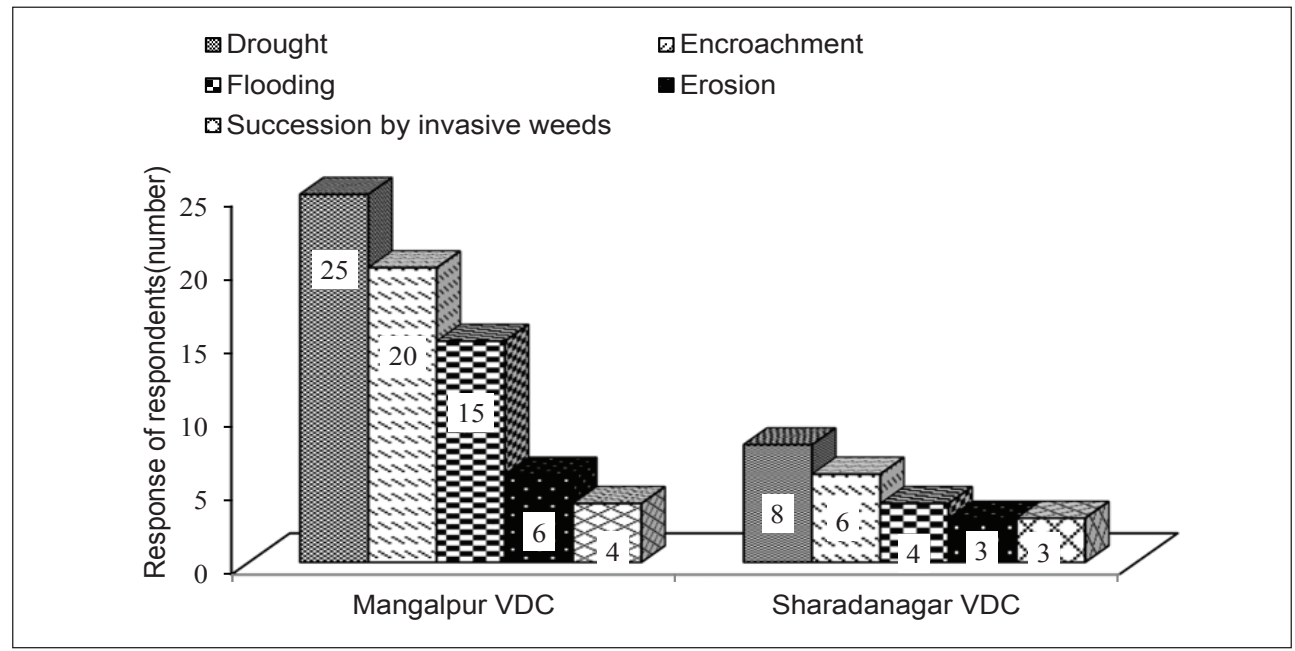

FIG. 3. Reasons behind change in wetland. 


\section{Impacts on wetland from community peoples}

Perception towards impacts by peoples: Study showed that among 83 respondents from Mangalpur VDC, majority of them (77.1\%) felt different types of impact on wetland (Fig. 4). While among 37 respondents from Sharadanagar VDC, majority of them $(86.5 \%)$ felt different types of impacts.

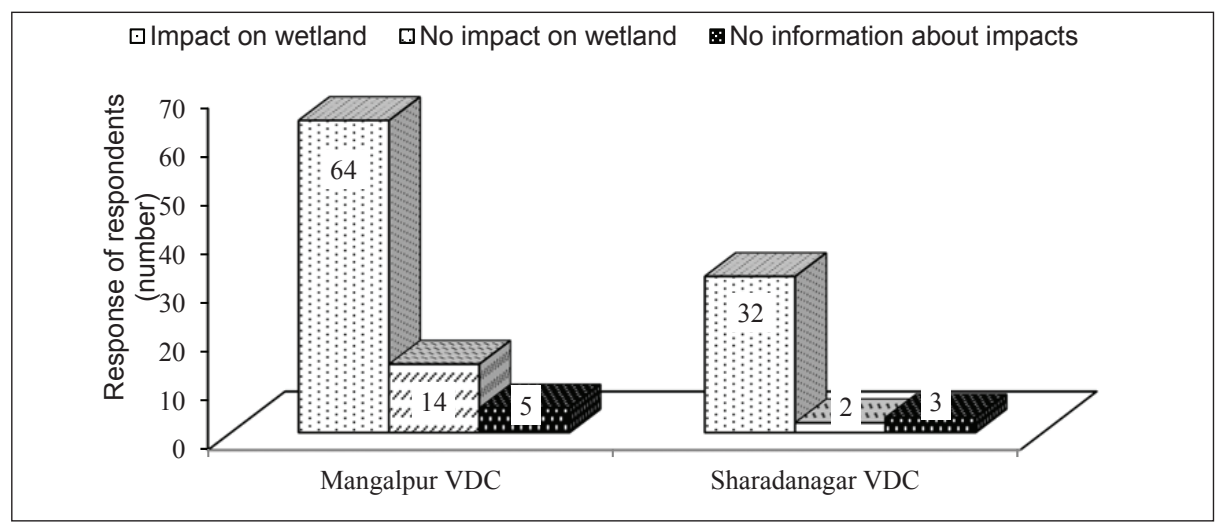

FIG. 4. Perception towards impactson wetland.

\section{Impacts by community people on wetland and their ranking}

The study showed that respondents from Mangalpur and Sharadanagar VDCs highlighted conversion for agriculture as most important impact with index value of 0.19 (table 2).

TABLE 2. Impacts on wetland on the basis of respondent's perception.

\begin{tabular}{|l|c|c|}
\hline Impacts on wetland & Index value & Rank \\
\hline Conversion for agriculture & 0.19 & I \\
\hline Discharge of pollutants & 0.16 & II \\
\hline Overexploitation of aquatic resources & 0.11 & III \\
\hline Animal grazing & 0.05 & IV \\
\hline Conversion for residential development & 0.04 & V \\
\hline Conversion for aquaculture & 0.01 & VI \\
\hline
\end{tabular}

Note: Scale value ranges from 1 to 0 , where $1=$ most serious, $0.75=$ serious, $0.5=$ moderate, $0.25=$ a little bit and $0=$ no problem

\section{Negative impacts of wetland to community people and their ranking}

The study showed that peoples from Mangalpur and Sharadanagar VDCs highlighted flooding as the most important negative impact of wetland to surrounding with highest index value of 0.31 (table 3). 
TABLE 3. Negative impacts of wetland to community people on the basis of respondent's perception.

\begin{tabular}{|l|l|l|}
\hline Negative impacts of wetland area & Index value & Rank \\
\hline Flooding & 0.31 & I \\
\hline Bad/foul smell & 0.22 & II \\
\hline Incidence of insect pest/disease & 0.05 & III \\
\hline Coldness in winter & 0.04 & IV \\
\hline Bank cutting/erosion & 0.03 & V \\
\hline
\end{tabular}

Note: Scale value ranges from 1 to 0 , where $1=$ most serious, $0.75=$ serious, $0.5=$ moderate, $0.25=$ a little bit and $0=$ no problem

\section{People's dependency on wetland}

Resource use pattern: Peoples around wetland depends on wetland for many purposes such as farming, fodder collection, fuel wood collection, medicinal plants, religious purpose, fishing, livestock grazing, wild edible plants, irrigation, commercial fishery, and recreational purpose (fig. 5).

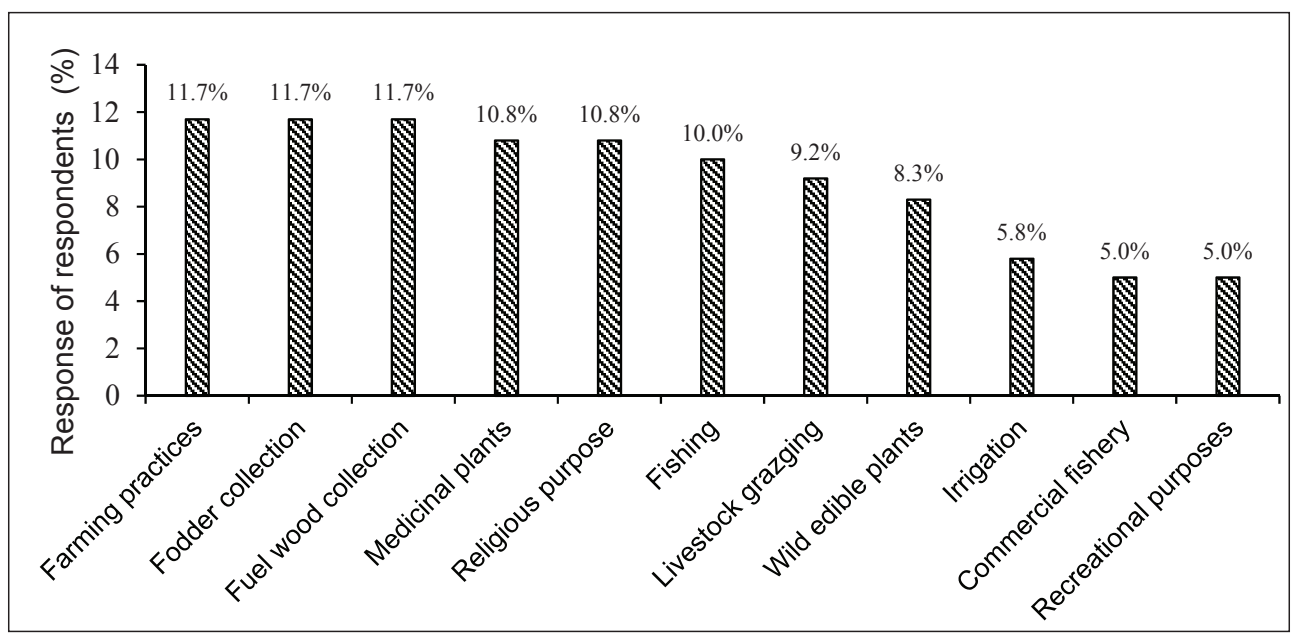

FIG. 5. Wetland resource use pattern by respondents.

Level of subsistence from wetland resources: The level of subsistence of respondents by the use of wetland resources (fig. 6) showed that majority of respondents $(80.8 \%)(n=120)$ were subsistence from use of wetland resource. 


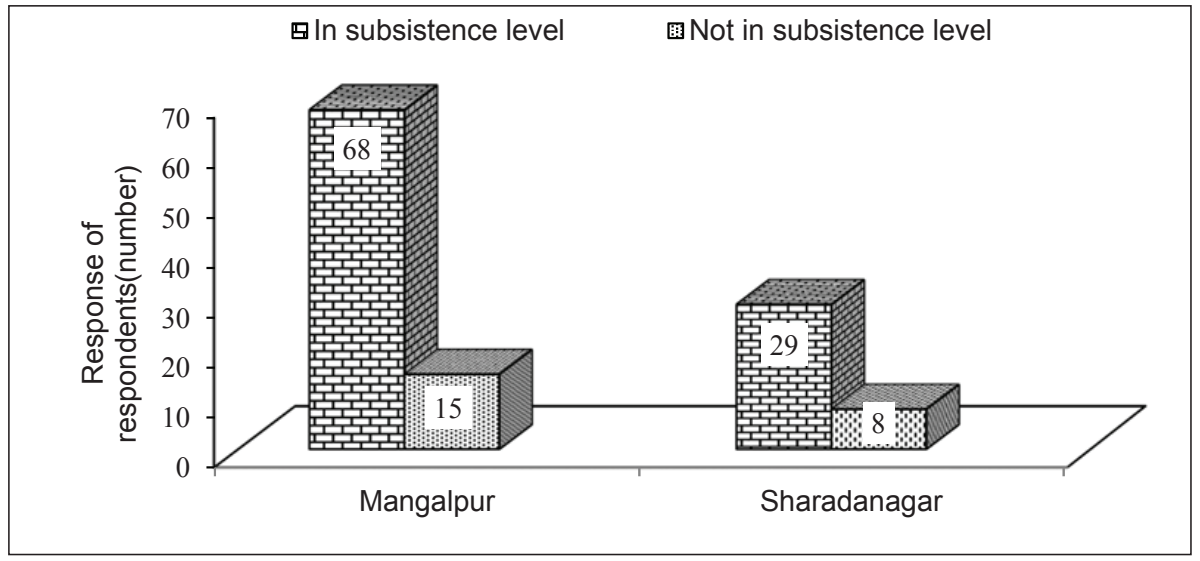

FIG. 6. Level of subsistence of respondents.

Contribution to economy from wetland resources:Majority of respondents (80.8\%) economic level uplifted from the utilization of wetland resources $(n=120)$ (fig. 7).

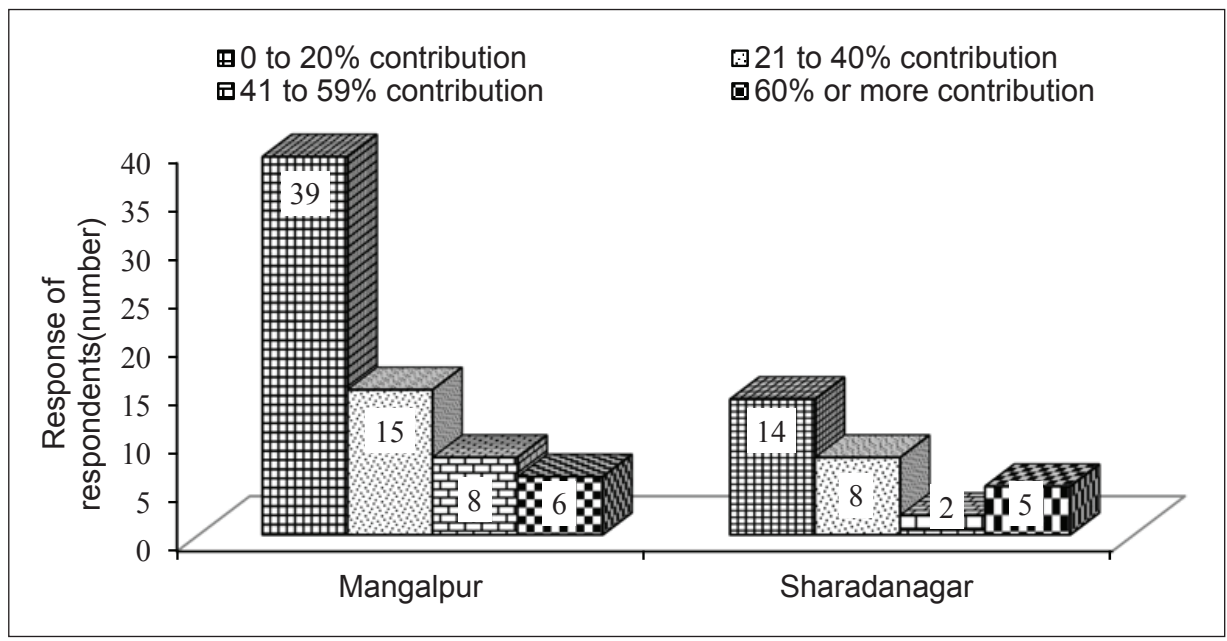

FIG.7. Wetland's contribution to economy of respondents.

Wetlands are becoming increasingly recognized as important natural resources in developing countries because of their ability to fulfill a range of environmental functions and produce a number of products that are seasonally and economically beneficial to local communities (Dugan, 1990; Silviuset al.,2000). Despite their value wetlands have suffered from wide spread destruction due to misuses and abuse (CP, 2005).

Wetlands are being changed rapidly over time in different parts of Nepal. Field survey revealed that majority of respondents $(78.0 \%)$ felt changes in Rampur wetland which are drying, decrease in acreage and biodiversity loss. It was found that reasons or factors for these 
changes were drought, encroachment, flooding, erosion and succession by invasive species. Bhandari (1998) reported that the wetlands are fast disappearing ecosystems of Nepal.Wetlands are constantly facing disturbances occurring within them and within the surrounding landscape due to natural or anthropogenic factors. These disturbances in wetland or by wetland to surrounding landscape are known as impacts of wetland. The wetland in study location was also facing impacts from peoples which wereconversion for agriculture, Discharge of pollutants, discharge of pollutants, overexploitation of resources, animal grazing, conversion for residential development, and conversion for aquaculture. The study also identified negative impacts of wetland on nearby peopleswhich are flooding, foul smell, incidence of insect pest, coldness in winter and erosion. Wetland being lowland and marshy type, it creates flood during monsoon season destroying crop plants. The study in Rampur wetland carried out by Small Earth Nepal also identified flooding, coldness in winter and foul smell as negative impacts to local peoples (SEN, 2010).It is important to recognize to what extent various disturbances affect wetlands when assessing disturbance and impact, and when considering wetland protection options (Clearwater, 1998). The deteriorating state of wetlands and consequent threats to sustainability of livelihoods remains a matter of concern to many governments, especially in developing countries.

The Nepalese communities use wetland resources for their sustenance and economic well-being (Bhandari, 1998). Study on resource use pattern peoples in Rampur wetland showed that they were dependent on wetland for farming, fodder collection, fuel wood collection, medicinal plants collection, religious purpose, fishing, livestock grazing, wild edible plant collection, irrigation, commercial fishery and recreational purpose.In contrast to IUCN (1996) which argues that majority of Nepal's wetland are used for fishing, wetland in study location used for multiple purposes. The farming practices include two season paddy cultivation; cultivation of maize, wheat, mustard, potato, beans and other green vegetables. The main species of fodder plant around marshy area is Leersiahexandrawhile, co-dominated, a legume species, Aeschynomeneindica, frequent weed of rice, as well as other grasses and sedges are collected by the farmer to feed the domesticated animals (Dangol, 1998-99). Local people collects drift woods from wetland area for the source of energy for cooking purpose. During times of scarcity, local people use their knowledge of wild plants to obtain vegetables for sustenance. The result of study also revealed that majority of respondents were subsistence from use of wetland resources and wetland also have contribution to uplift their economy. While all Nepali people benefit directly or indirectly from wetlands, the livelihoods of several communities are based on wetland products or services. The indigenous caste people 'Tharus' and 'Darai' were most dependent on wetland for their livelihood mainly for fishing in study location. The IUCN report lists 20 of ethnic groups as traditionally wetland dependents (Bhandari, 1998). These wetland dependent communities are some of the poorest and most marginalized peoples in Nepal. Therefore, wetland is critical for contributing to poverty reduction if managed and used wisely. There is need of responsible stakeholders for their active involvement involving local peoples in conservation and management to protect from wetland loss.

\section{ACKNOWLEDGEMENTS}

We would like to thank University Grants Commission (UGC), Bhaktapur for financial support to conduct Rampur Wetland Project. A special thank goes to the local peoples and others for active participation in household survey, focus group discussions and key informants interview. 


\section{REFERENCES}

ADHIKARI, S ; BAJRACHARAYA, R M ; SITAULA, B K (2009) A review of carbon dynamics and sequestration in wetlands. Journal of Wetlands Ecology 2:42-46.

BHANDARI, B (1998) Wise use of wetland resources: lessons drawn from selected wetland sites of Nepal's Terai region. Case study No. 13. In Community participation in wetland management: lessons from the field. Available at http://www.wetlands.org/pubs\&/proc_pub.html\#download.

CBS (2011). National population and housing census 2011.Volume 2: 60.Central Bureau of Statistics (CBS), Kathmandu, Nepal.

Clearwater (1998) Acomprehensive non-tidal wetland watershed management plan: aguide for localgovernments.Maryland Department of the Environment, New York, USA.

CP (2005) The Colombo plan (CP). Focus, Issue 33, October 2005.

DANGOL, D SR (1998-99) An inventory of plant biodiversity of Rampur, Chitwan, Nepal. J Inst Agric AnimSci 18-19: 27-40.

DENNY, P (1995) Benefits and priorities for wetland conservation: the case for national wetland conservation strategies. In COX, M; STRAKER, V; TAYLOR, D (eds) Wetland archaeology and nature conservation. Proceedings of international conference on wetland archaeology and nature conservation,UK.

DUGAN, P J (1990) Wetland conservation: a review of current issues and required action. IUCN, Gland, Switzerland.

IUCN (1996) An inventory of Nepal's wetlands. International Union for Conservation of Natural Resources (IUCN), Nepal.

IUCN (2004) A review of the status and threats to wetlands in Nepal. IUCN, Nepal.

Kabii, T (1996) An overview of African wetlands. In HAILS, A J (ed) Wetlands, biodiversity and the Ramsar convention. Switzerland.

MEA (2005) Ecosystems and human wellbeing: wetlands and water synthesis. World Resources Institute, Washington DC, USA.

MFSC (2002) Nepal biodiversity strategy. Ministry of Forest and Soil Conservation/UNDP,Kathmandu, Nepal. MIAH, A Q (1993) Applied statistics: a course handbook for human settlements planning. Asian Institute of Technology, Division of Human Settlements Development,Bangkok, Thailand.

MWAKAJE, A G (2009) Wetlands, livelihoods and sustainability in Tanzania. African Journal of Ecology 47(s1):179-184.

SEN (2010) A research report on baseline study of Rampur Ghol, Chitwan, Nepal. The Small Earth Nepal (SEN). A Report to International Hydrological Program, IHP, Nepal/UNESCO, Nepal National Water Week 2010, Nepal; 23p.

SILVIUS, M J; ONEKA, M; VERHAGEN, A (2000) Wetlands lifeline for people at the edge. Physics and Chemistry of the Earth (B) 25(7-8): 645-652.

SONOBE, K; USUI, S (1993) A field guide to the waterbirds sof Asia. Wild Bird Society of Japan, Tokyo, Japan.

TERER, T; NDIRITU, G G ; GICHUKI, N N (2004) Socio-economic values and traditional strategies of managing wetland resources in lower Tana River, Kenya. Hydrobiologia 527(1): 3-15.

WI (2006) Millennium ecosystem assessment report: Ecosystem and human well-being. Wetland International (WI), Ede, Netherlands. 